\title{
Oriental(ized) Portuguese-Anglophone Literature, Culture, and Colonial Stereotypes
}

\section{David BROOKSHAW}

The root of stereotypes is prejudice, and the root of prejudice, according to Gordon Allport (1954), is the need felt by one human group to define itself against another or others. During the period of European imperialism, colonial rule was upheld and underpinned by prejudice, which in turned was justified by theological and, in the course of time, pseudo-scientific theory. African slavery in the New World was justified by the notion that the forced migration of slaves brought them into Christendom, and therefore freed their souls to enjoy the afterlife, while later, their continued enslavement and/or abandonment at the bottom of the social pyramid could be explained by their inherent backwardness, now bolstered by Social-Darwinist theories. At the same time, all manner of specific stereotypes emerged to allow the dominant group to assuage its conscience by 're-fencing' its

1 University of Bristol; D.R.Brookshaw@bristol.ac.uk 
prejudice, to use another of Allport's term (1954, p. 23). The dangers (and delights of - or right to) consort with the female slave among slaveowners and their offspring, brought with it the idea that the slave woman was naturally lustful. In Brazil, of course, this witnessed the birth of all the mythology surrounding the 'mulata', elevating the female born within slavery (or indeed out of it) to a female fantasy figure for the dominant white male. Yet during the nineteenth century, when slavery began to be questioned, and an abolition campaign mounted in literature, a new stereotype emerged: that of the suffering slave woman, as depicted in fiction, drama and poetry. This detail will become relevant later in this paper, when we discuss the subject of the Eurasian female in fiction about Macau or the Macanese.

But prejudice and stereotypes were not just the product of the top-down culture of social control within colonial society, the maintenance of what in effect amounted to a caste system. Prejudice emerged out of colonial rivalries. A number of colonial rivals were, of course, European neighbours, with a history of cross-border suspicion and hostility (England/France, Portugal/ Spain), but the biggest rift occurred between Northern and Southern Europe, based as it was on religious difference. The Black Legend, which portrayed the Spanish as fanatical, cruel and bigoted, may have been born elsewhere, but it was widely used in anti-Spanish propaganda in England, as Tudor and then Stuart England sought to carve out its own imperial space in the New World. This prejudice against a supposedly prejudiced Spain was to outlive the century or so of Spanish colonial supremacy, to later feed the nineteenth-century 'romantic' view of Spain projected by writers such as Washington Irving and Prosper Merimée: a Spain of Moorish castles, gispsies, and flamenco, in short, an orientalized Spain, still fanatical, but now 
're-fenced' as exotic other. In other words, behind every negative stereotype, there was the potential for a supposedly positive, attractive, and interesting alternative. It is important to bear in mind this violent, dangerous, but exotically seductive depiction when reading Charles A. Gunnison's short story, 'In Macao'.

\section{The Oriental(ized) Portuguese male}

Gunnison (1861-97), who was the secretary of the Commercial Publishing Company in San Francisco, published 'In Macao' in $1892^{2}$. Set in Macau, as the title indicates, it mingles elements of romanticism with gothic horror, as two critics have pointed out (PugA, 2011; SHAw, 2011). The narrator tells the story of his uncle, Robert Adams. The tale opens with the narrator sitting near the Camoens Grotto, when a priest sits down next to him and engages him in conversation, and begins to tell him about Goa. Suddenly, the narrator's uncle, Robert, appears from under a great banyan tree, the priest jumps up and attacks him with a knife, but is gunned down. The bulk of the story is then a long flashback to explain this action, leading us eventually back to the opening scene of the tale.

Robert Adams, the narrator's uncle, was a New Englander, "as good a specimen of Anglo-Saxon youth as England herself could boast of. He was the last descendant of a New England family, which had preserved its purity for three centuries as unmixed with continental blood as though the three centuries had been passed in the quiet vales of Devon, instead of in the New World with its broken barriers". After college, he had

2 Available at: < http://www.gutenberg.org/files/18658/18658-h/18658-h.htm_>. Accessed on June 6, 2017. 
gone to work in a shipping office in Hong Kong, "which the sickly American commerce of the day was able to support in the once flourishing China trade". There, in the course of time, he had met Priscilla, orphaned offspring of a New England couple, who had been brought up in Macau by her aunt, the second wife of Dom Luiz de Amaral, a local grandee: "it was a strange transplanting for such a flower from the cold coast of Puritan New England to the tropical, Roman Catholic colony in the heart of heathendom. But the flower of so sturdy stock remained true".

It had long been assumed that Priscilla would marry Dom Luiz's son, Dom Pedro de Amaral, by his first marriage to a Spanish woman. We can only guess why Gunnison had made D. Pedro half-Spanish, but that old stereotype of passion and violence was readily available, and while Macau was a Portuguese colony, the stereotype could be transferred with impunity by the agents of a culture that saw little, if any difference, between Portuguese and Spaniards. As we shall see, the use of the stereotype may indeed have had wider geopolitical ramifications. However, to return to the plot, Priscilla had been introduced to the wider world of Hong Kong by her foster parents, and it was there that she met Robert: "There were many disappointed youths and envious of Robert Adams, but all took their misfortune as in the way of the world, except young Amaral, who, in silence, had watched the course of events and now hated the happy suitor with all the fierceness of his Southern blood".

The situation is complicated by the fact that Adams is a friend of the Amaral family. D. Luiz's fortune has been built on his wise investments in Hong Kong and in trade, unlike most of his fellow citizens who live in poverty and pride, including his son, who is an inveterate gambler. It is on one such gambling expedition that D. Pedro persuades Robert, who is visiting 
Priscilla, by now his fiancée, to join him. After their visit to the gambling den, Robert decides to take a late night stroll among the ruins of St Paul's Church, where he is set upon and stabbed in the arm with a poisoned dagger, creating a stir in Macau not felt since the assassination of the Governor Amaral ${ }^{3}$.

The same night, Priscilla mysteriously disappears. Robert has to have his arm amputated, and after some weeks, during which time there is no news of his betrothed, the now recovered Robert receives a cryptic message instructing him to make for a junk anchored in the harbour. There he finds Priscilla, while he himself has been lured there by D. Pedro, his sweetheart's kidnapper. D. Pedro's intention is to force a marriage with Priscilla and, we assume, to dispose of Robert. However, at this point, nature intervenes in the form of a typhoon, which destroys the junk. Both, being good swimmers (even the one-armed Robert), the two are saved and return to D. Luiz's house. As for D. Pedro, he survives with a broken arm, but Priscilla develops a fever and eventually dies. We assume that D. Pedro, who disappears shortly afterwards to Hong Kong, either joins the priesthood, or perhaps runs away to Goa, as suggested at the beginning of the story.

There is, of course, nothing new in the figure of the sinister villain, who inhabited tales of gothic horror in the literature of the first half of the nineteenth century, but the racial/ racist references to $\mathrm{D}$. Pedro are, it could be argued, pertinent to a particular period of history. Gunnison lived through a time of transformation in his native California, and indeed in the history

3 João Maria Ferreira do Amaral (1803-1849) was a Portuguese naval officer appointed to the governorship of Macau in 1846. He pursued policies that were seen by the regional Chinese elite as hostile to their interests, and was assassinated in 1849. News of his death shocked the colonial authorities of Macau and Hong Kong, and the publicity given to the event may be why Gunnison used the family name in his story. 
of the United States and its relationship with what might broadly be termed, the Iberian and Ibero-American world. The year 1848 witnessed the formal surrender by Mexico of California to the United States, as a result of the US-Mexican War (18461848). The opening up of the North American western seaboard to a rapidly expansive United States paved the way for further incursions into the Pacific, culminating in the seizure of the Philippines in 1898 resulting from the brief war with Spain. If, in parallel to this, we also consider the establishment of Hong Kong as a British colony in 1841, which severely dented the historic prestige of Portuguese Macau as the only European entrepot in China, then we could regard the second half of the nineteenth century as a period of unbridled Anglo-American capitalist expansion at the expense of the older Iberian empires in the Western Pacific and South China Sea. It is important to bear this process in mind when reading 'In Macao', for it explains the stereotyped portrayals of Robert, "as good a specimen of AngloSaxon youth as England herself could boast of" and of Pedro de Amaral, his failed rival for the hand of Priscilla, who "bent upon him such a look of hatred as only the eyes of Latin races can give", and "hated the happy suitor with all the fierceness of his Southern blood". This hatred is accentuated by the fact that Priscilla has been brought up in Macau. Robert is therefore the rescuer of one of his own stock from the threat of race mixture.

A brief look at two of Gunnison's other short stories available in the same volume as 'In Macao' places him well within the vein of romantic Indianism associated in North America with figures such as Fennimore Cooper, and in South America with the Brazilian, José de Alencar. 'The beautiful 
eyes of Ysidria'4 and 'A Napa Christchild'5 are both set in the author's native California, at a time before its incorporation into the United States, but when the first Yankee settlers and traders were beginning to make incursions into the area, a period that corresponded to the narrator's youth, "those merry days of California before the gold was about her dear form like prisoner's chains; before the greed of the States and England had forced us into the weary drudgery of the earth, and made us the slaves of misbegotten progress" ${ }^{\prime \prime}$. Gunnison, like both Cooper and Alencar, was ambiguous about the merits of conservation and the inevitability of progress, and it is precisely this depiction of an older world, but which is threatened by change, that is visible in the author's depiction of Macau, at once beautiful, placid and at one with Nature, but dangerous, secretive, venomous towards that or those which threaten its static order. The idea is that just as exotic beauty may conceal an underlying ugliness, the old cannot give way to the new without extracting a high price and a violent outcome: "On the yellow water here and there were junks with tanned sails and gay banners; islands with graceful pagodas were seen, and the huge white cathedral of the near dependency of Taipa. Then in the foreground at their very feet was Macao, a feast of colour, red roofs, many-hued walls, green trees and brilliant gardens, beautiful as the jewel-set sheath of a Venetian dagger, with its poison and death-dealing wickedness hidden".

This attraction to the 'Other', coupled with fear and revulsion, is a characteristic of colonial literature and of what

4 Available at: 〈https://www.gutenberg.org/ebooks/18660〉. Accesed on June 6, 2017.

5 Available at: 〈https://www.gutenberg.org/ebooks/18725〉. Accessed on June 6, 2017.

6 'The beautiful eyes of Ysidria'. 
we now understand by the blanket term Orientalism, and this is most tangibly reflected in the figure of the male 'Other', who, in accordance with the morality of the colonizer, is feminized. Nowhere is this more clearly reflected in the figure of the open, honest, upright Robert Adams, on the one hand, and the emotional but devious Pedro de Amaral on the other, and in the former's upbraiding of the latter during his brief imprisonment on the junk: "I thought you my friend, Dom Pedro, and I thought you a man (my stress)". If Robert and Priscilla, the archetypal innocent victim, are saved from the vengeance of Dom Pedro by a typhoon, this excess of Nature merely serves as a metaphor for the violence and chaos of Dom Pedro's 'Otherness'. Equally, Robert's replacement of Pedro as Dom Luiz de Amaral's trusted adviser and honorary son seems to suggest a type of compromise at the end between old fashioned concepts of honour and decency enshrined in the decadent Pedro's father, who significantly, has made shrewd investments in Hong Kong to ensure his position in Macao's wealthy elite, and progressive capitalism enshrined in Robert, the young, "pure-blooded" Anglo-Saxon New Englander, drawn to the East by the opportunities afforded by Hong Kong. However, the long arm of vengeance impedes even this new association, and the scene of departure at the end of the story seems to throw into relief Macau's general abandonment and stasis, which of course, have been commented on throughout the tale, with references to Macau as a "drowsy city", whose residents sleep during the week and awaken on Sundays, a timetable diametrically opposed to that of puritanical, Protestant capitalism. 


\section{The Oriental(ized) Portuguese female}

We now move on to the figure of the 'orientalized' Portuguese female, while also fast-forwarding seventy years to the Hong Kong of James Clavell. Clavell (1924-94) was a British writer, now remembered mainly for his blockbuster novels set in East Asia, most of which were turned into films or TV miniseries. In fact, Clavell settled in Hollywood in the early 1950s, and became a film scriptwriter, counting among his major successes, 'The Great Escape' and 'To Sir with Love'. The links between the cinema and stereotypical characterization will be returned to later, but for now, suffice to say that the novel that interests us here is Noble House (1981). Noble House is a sequel to Clavell's earlier novel, Tai-Pan, which was set in Hong Kong in the 1840s, and traced the emergence of two trading houses, and two bitter rivals for commercial hegemony, Dirk Struan and Tyler Brock, the founders of enterprises loosely based on the real life Hong Kong trading houses of Jardine-Mathieson and Butterfield \& Swire. Hong Kong in the early 1960s is of course, very different and far more complex. Ian Dunross is now 'tai-pan', or chief executive of Struan's, and family rivalry with Rothwell-Gornt, led by Quillan Gornt, a descendant of Tyler Brock, still forms the central pivot for all that happens. Against a general background of espionage and counter-espionage (we are at the height of the Cold War - the Cuban missile crisis, US involvement in Vietnam, the Profumo scandal), and Triad activity, Struan-Gornt rivalry is spiced up by the arrival of two American entrepreneurs, Linc Bartlett, buccaneering president of Par-Con Industries and his vice-president, Casey Tchulok, with whom he is rumoured to be sexually involved. Bartlett is in Hong Kong to seek investment partners and to make a quick profit out of the Hong Kong boom, 
but he is undecided whether to invest in Gornt or in Struan. Both are potentially willing partners, Struan because he is overstretched as always with loans to repay, Gornt because he sees Bartlett as a conduit to his taking over Struan's and becoming the one and only 'tai-pan', much as his nineteenth-century ancestor had tried and failed to become. In his effort to win over Bartlett to the Gornt camp, Quillan deploys his most seductive weapon: Orlanda Ramos. Orlanda is the daughter of a Chinese mother and a Portuguese father from Macau. Born in Shanghai, she was sold to Quillan by her indebted parents, as a 'mui jai' (in effect, a slave girl). Educated in the United States until she was eighteen, she had returned to China to become Quillan's mistress, and even though they are no longer romantically involved with each other, she remains dependent on him.

Orlanda is not unlike generations of 'mestizo' women portrayed in Latin American literature. Morally ambiguous, we are never sure whether her seduction of Linc Bartlett is to secure her own position with Gornt, or done out of genuine attraction for the American, or whether it is the offer of rewards from Gornt: if she succeeds in becoming his mistress, she will get a Jaguar and the flat she lives in in Hong Kong, if she becomes his wife, she will get the additional reward of a house in San Francisco. On the other hand, all the characters in the book are driven by the pursuit of material gain, and prostitution is merely a way in which women can get a slice of wealth produced by men. In a world where women are enslaved by men, then Orlanda's pursuit of Bartlett can be seen as an act, which, if successful, will free her from Gornt, but of course, only to become a slave of Bartlett. And this is where Orlanda, the sex puppet, becomes the tragic slave woman. Firstly, we are made aware that she had a child by Gornt, now being raised in Portugal, to where her family 
fled after the fall of Shanghai to the Communists in 1949. The separation of mother and child within slavery was a trope that anti-slavery writers in the New World used in literature in the second half of the nineteenth century in order to emphasize the inhumanity of the institution. In Orlanda, there is still a dream of reconciling the pieces of her shattered world, by taking Bartlett one day to visit her family in Portugal, by freeing herself from the limiting label of being classified in the strict social hierarchy of colonial Hong Kong as a Eurasian, and by escaping her past and disappearing into the American melting-pot, where one's ethnic origin can be forgotten or re-invented. Orlanda's tragedy is that she seeks to throw off the shackles of the stereotype that she has been forced to accept of herself.

The ultimate tragedy is one of irony. At the onset of a devastating typhoon, Orlanda and Linc eventually 'pillow' (the term used locally throughout the book meaning to have sex). As Bartlett, sleeps in her bed, Orlanda goes out to buy some food, only for the apartment block to collapse when it is hit by a landslide. As attempts are made to rescue him, a further slide obliterates the remains of the building, and the American dies. This not only shatters Orlanda's dream, but also symbolically marks the end of Gornt's dream to take over Struan's. The tower block was one of the first to be put up in the post-war boom by Gornt, with uninterrupted views of the harbour. Struan had put up another skyscraper partially blocking this view, much to his business rival's resentment, but the fact that Struan's concrete phallus survives and Gornt's does not seems to reflect the outcome of the story, namely Gornt's ultimate failure to topple Dunross.

But perhaps the greatest irony in this story is that Orlanda's real guardian angel is in fact another woman, 
her supposed love rival, Casey. It is Casey, the embodiment of American beauty, athleticism, and the values of venture capitalism, who saves Orlanda's life during a fire on a floating restaurant when it transpires that the terrified Orlanda cannot swim. It is Casey who goes to meet Orlanda after the final tragedy. Orlanda has succumbed to what is seen as native fatalism: "Joss about Linc, she told herself for the ten thousandth time. Joss. Now everything's as before. Everything has to start again. The gods laughed at me again. Perhaps there'll be another chance of course there'll be another chance. There are other men... Oh God! Don't worry, everything will be as it was. Quillan said not to worry, my allowance would contin" (CLAVELL, 1981, p. 1276).

Casey, who has made a large amount of money on the side, unbeknown to Bartlett, in a separate deal with Dunross, suggests a way out for her:

"on a sudden impulse Casey said, 'Why not try the States? Maybe I could help you find a job'.

'What?'

'Yes. Perhaps in fashion - I don't know what exactly but I'll try'.

Orlanda was staring at her incredulously. 'You'd help me, really help me?'

'Yes'. Casey put the envelope and her card on the table and got up, her whole body aching. 'I'll try'.” (CLAVELL, 1981, p. 1278)

Whether Orlanda will take her up on her offer or fall back into dependency on Gornt is left open at the end of the novel, while Casey returns to America. The film version has a 
less ambiguous ending, in keeping with romantic Hollywood convention: Orlanda is left with Quillan, while Casey has a brief affair with Dunross (appropriately played by Pierce Brosnan), promising to return to Hong Kong. Hollywood therefore maintains the nineteenth-century literary convention of punishing the ambitious, dark-skinned female for aspiring to rise beyond her station, while rewarding the light-skinned female with the possibility of the male hero's hand.

The two stereotypes we have considered here, the orientalized 'Portuguese' male and female emerged out of history, like other stereotyped images, the history of European colonialism and colonial rivalry. But they linger on after their time has passed. The excessively formal, phlegmatic Englishman, such a figure of fun among continental Europeans, seems as out of place now in our globalized age, as does the vindictive Latin. Moreover, there is evidence to suggest that in the late medieval and early Tudor periods, life was as violent and licentious as that stereotyped in later English depictions of foreign countries. The formal, efficient and moralistic Englishman emerged during Britain's imperial expansion, and was an English creation in so far as it embodied qualities inculcated in the male pupils of its elite schools, precisely those who would become the political leaders and administrative officials of empire. The same culture, in its own rivalry with Southern Europe, created the venal, immoral, vindictive foreigner, and in its religious scorn was clearly an arm of Protestant nationalism. The so-called Britain of the 'stiff upper lip' became redundant with the end of empire and the destabilising of older more deferential values during that watershed decade of the 1960s, when the social mobility facilitated by the welfare state, and state education system instituted after the Second World War, saw a first generation 
come of age and take on some of the values of 'rock' culture emanating from the United States.

\section{Orientalized Portuguese for Postmodernity}

If Europe has changed out of all recognition since the end of empire, stereotypes continue to abound in popular culture, a popular culture dominated now, no longer by the printed word, but by cinema (we only have to think of Hollywoodian visions of aristocratic Britain and the British that are totally dated, not to mention stereotypes of Latin Americans). The 2012 James Bond movie, 'Skyfall', takes us back to Shanghai and Macau as Bond (played by Daniel Craig) is sent to pursue the villain who has succeeded in destroying the headquarters of MI5 in London by some form of computerized remote control. From Shanghai, Bond is led to Macau by the discovery of a gambling chip found on a dead body. In a Macau casino, he encounters Sévérine (played by the Franco-Chinese actress Bérénice Marlohe), enslaved to the sex trade and to the villain, Silva, alias Tiago Rodrigues (played by Javier Bardem). Sévérine could be Orlanda, as she lures Bond to the offshore island that has been taken over by Silva in the hope that he might save her from her enslavement, Silva could be Pedro de Amaral from Gunnison's story, driven by a lust for vengeance against a world he feels has treated him badly. Silva's rancour is a measure of his inability to behave like a man - that is, to show a stiff upper lip. There is, however, a difference between the portrayals of Silva and Sévérine in the Bond film, and that of the earlier literary models considered above.

Despite the circumstantial link with Macau, their Portuguese identity is never mentioned, but somehow assumed. 
They are orientalized Latins who are Portuguese by geographical association or by name. Silva's identity is fluid, including his sexuality, as witnessed in his implied gay propositioning of his briefly imprisoned Bond. He was an MI5 operative in Hong Kong between 1986 and 1997, significantly the year of the handover of the territory to China. Silva may well be a Hong Kong Portuguese. Sam Mendes, who directed 'Skyfall' is himself from a Trinidadian family of Portuguese background, and would have been aware of the presence of people of Portuguese origin resident in the British colonial world. Abandoned by his employers, Silva's bitterness is turned against the British Empire and what he sees as Bond's misguided attachment to country. He seeks to seduce him, in an openly homo-erotic moment of behaviour, away from traditional concepts of patriotism and manhood. Silva is a de-racinated, postmodern orientalized Portuguese for the international world of internet technology and globalization, but the familiar basis of the stereotype, notably vindictiveness and brutality, is nevertheless present.

Finally, it would be untrue to suggest that Northern European imperial hubris went unanswered by its Southern European rivals. The fact is that all colonial nations extolled their own exceptionality in the great imperial contest. At about the same time that the elite schools of Britain were training the future administrators of the colonial empire in the virtues of stoicism and detachment, a Brazilian sociologist, Gilberto Freyre, was embarking on a social and cultural history of slavery in the North East of his country that would eventually lead to his re-interpretation of the nature and qualities of Portuguese colonialism, not only in Brazil, but in Africa and in Asia. Ultimately, what was to become the theory of Luso-Tropicalism turned some of the negative stereotypes of Portuguese colonialism 
as propounded by the British into essentialist, positive qualities: informality, unbridled sexual activity, and the blurring of social and cultural boundaries between colonizer and colonized through miscegenation. In the final stages of the Portuguese Empire, the exceptional quality of Portuguese colonialism, according to the political narrative of Lisbon, once it took on board Freyre's theories, lay in the selective 'orientalization' of its colonial agents as an antidote to that which was perceived as rival British arrogance, exclusiveness and ultimate colonial failure.

\section{References}

Allport, G. W. The nature of prejudice. Cambridge MA:

Addison-Wesley, 1954.

Glavell, James. Noble House. London: Hodder \& Stoughton, 1981.

PugA, Rogério. The picturesqueness of sleepy Macao: singularity of space in a short story by Charles A. Gunnison. Oriente, n. 1, v. 1, p. 108-118, 2001.

SHaw, D. In Macao: Charles A. Gunnison's gothic tale. Journal of the Macao Polytechnic Institute, n. 5, p. 31-38, 2011.

Brookshaw, David. Oriental(ized) Portuguese - anglophone literature, culture, and colonial stereotypes. In: Simas, Monica (Org.). Estudos sobre Macau e outros orientes. São Paulo: Paulistana, 2017. p. 95-110. 